\title{
Chemical and Biological Enhancement Effects of Biochar on Wheat Growth and Yield under Arid Field Conditions
}

\author{
Zarmeena Khan ${ }^{1}$, Muhammad Habib ur Rahman 1,2,*iD, Ghulam Haider 1,3, Rabia Amir ${ }^{3}$, \\ Rao Muhammad Ikram ${ }^{1}$, Shakeel Ahmad ${ }^{4}$, Hannah Kate Schofield ${ }^{5}$ (D) Bilal Riaz ${ }^{1}$, Rashid Iqbal ${ }^{6}$ D, \\ Shah Fahad ${ }^{7, * \mathbb{D}}$, Rahul Datta ${ }^{8, * \mathbb{D}}$, Alaa Baazeem ${ }^{9} \mathbb{D}$, Ayman EL Sabagh ${ }^{10} \mathbb{D}$ and Subhan Danish ${ }^{11, * \mathbb{D}}$
}

check for updates

Citation: Khan, Z.; Rahman, M.H.u.; Haider, G.; Amir, R.; Ikram, R.M.; Ahmad, S.; Schofield, H.K.; Riaz, B.; Iqbal, R.; Fahad, S.; et al. Chemical and Biological Enhancement Effects of Biochar on Wheat Growth and Yield under Arid Field Conditions. Sustainability 2021, 13, 5890. https://doi.org/10.3390/su13115890

Academic Editors: Marc A. Rosen, Ram Swaroop Meena,

Sandeep Kumar and Manoj Kumar Jhariya

Received: 12 March 2021

Accepted: 18 May 2021

Published: 24 May 2021

Publisher's Note: MDPI stays neutral with regard to jurisdictional claims in published maps and institutional affiliations.

Copyright: (c) 2021 by the authors. Licensee MDPI, Basel, Switzerland. This article is an open access article distributed under the terms and conditions of the Creative Commons Attribution (CC BY) license (https:/ / creativecommons.org/licenses/by/ $4.0 /)$.
1 Department of Agronomy, MNS-University of Agriculture, Multan 60000, Pakistan; zarmeenakhan335@gmail.com (Z.K.); haideruaf@gmail.com (G.H.); rao.ikram@mnsuam.edu.pk (R.M.I.); bilalr930@gmail.com (B.R.)

2 Crop Science, Institute of Crop Science and Resource Conservation (INRES), University of Bonn, 53115 Bonn, Germany

3 Department of Plant Biotechnology, Atta-Ur-Rahman School of Applied Biosciences, National University of Sciences and Technology (NUST), Islamabad 44000, Pakistan; rabia@asab.nust.edu.pk

4 Department of Soil Science, MNS-University of Agriculture, Multan 60000, Pakistan; shakeel.ahmad@mnsuam.edu.pk

5 Biogeochemistry Research Centre, School of Geography, Earth and Environmental Science, University of Plymouth, Plymouth PL4 8AA, UK; kate.schofield@plymouth.ac.uk

6 Department of Agronomy, Faculty of Agriculture \& Environment, The Islamia University of Bahawalpur, Bahawalpur, Punjab 63100, Pakistan; rashid.iqbal@iub.edu.pk

7 Department of Agronomy, The University of Haripur, Haripur 22620, Pakistan

8 Department of Geology and Pedology, Faculty of Forestry and Wood Technology, Mendel University in Brno, Zemedelska1, 61300 Brno, Czech Republic

9 Department of Biology, College of Science, Taif University, P.O. Box 11099, Taif 21944, Saudi Arabia; aabaazeem@tu.edu.sa

10 Department of Agronomy, Faculty of Agriculture, Kafrelsheikh University, Kafrelsheikh 33156, Egypt; aymanelsabagh@gmail.com

11 Department of Soil Science, Faculty of Agricultural Sciences and Technology, Bahauddin Zakaria University, Multan 60800, Pakistan

* Correspondence: mhabibur@uni-bonn.de (M.H.u.R.); shah_fahad80@yahoo.com (S.F.); rahulmedcure@gmail.com (R.D.); sd96850@gmail.com (S.D.); Tel.: +92-304-7996951 (S.D.)

\begin{abstract}
Nitrogen $(\mathrm{N})$ losses are prevalent under South East Asia's due to high $\mathrm{N}$ fertilizer inputs, but low $\mathrm{N}$ fertilizer use efficiency. This leaves a large quantity of reactive $\mathrm{N}$ at risk of loss to the environment. Biochar has been found to reduce $\mathrm{N}$ losses across a variety of soil types, however, there is limited data available for semi-arid climates, particularly at a field-scale. Herein we present an exploration of the biological and chemical enhancement effects observed of a cotton stalk-based biochar on wheat growth and yield under arid field conditions. The biochar was treated with urea-N and biofertilizer (bio-power) in different treatment setups. The six experimental treatments included; (i) a full $\mathrm{N}$ dose "recommended for wheat crops in the region" $\left(104 \mathrm{~kg} \mathrm{~N} \mathrm{ha}^{-1}\right)$ as a positive control; (ii) a half $\mathrm{N}$ dose $\left(52 \mathrm{~kg} \mathrm{~N} \mathrm{ha}^{-1}\right)$; (iii) a half $\mathrm{N}$ dose + biofertilizer $\left(4.94 \mathrm{~kg} \mathrm{ha}^{-1}\right)$ as a soil mixture; (iv) a half $\mathrm{N}$ dose + biofertilizer as a seed inoculation; (v) a full $\mathrm{N}$ dose as broadcast + biochar $\left(5 \mathrm{tha}^{-1}\right)$ inoculated with biofertilizer; and (vi) a full $\mathrm{N}$ dose loaded on biochar + biofertilizer applied as a soil mixture. The half dose $\mathrm{N}$ application or biofertilizer addition as soil mix/seed inoculated/biochar inoculation with biofertilizer caused reduced wheat growth and yield compared to the control (conventional $\mathrm{N}$ fertilization). However, co-application of chemically enhanced biochar (loaded with a full $\mathrm{N}$ dose) and biofertilizer as soil mixture significantly increased the crop growth rate (CGR) and leaf area index (LAI). A significantly higher crop growth and canopy development led to a higher light interception and radiation use efficiency (RUE) for total dry matter (TDM) and grain yield (11\% greater than control) production compared to the control. A greater grain yield, observed for the full $\mathrm{N}$ dose loaded on biochar + biofertilizer applied as a soil mixture, is attributed to prolonged $\mathrm{N}$ availability as indicated by greater plant and soil $\mathrm{N}$ content at harvest and different crop growth stages, respectively. The present study has improved our understanding of how the application of
\end{abstract}


nitrogen loaded biochar and biofertilizer as soil mixtures can synergize to positively affect wheat growth and soil-nitrogen retention under arid environmental conditions.

Keywords: $\mathrm{NO}_{3}{ }^{-}-\mathrm{N} ; \mathrm{NH}_{4}-\mathrm{N}$; canopy growth; IPAR; RUE; pollution; wheat; food security

\section{Introduction}

The increasing food demands of an ever-increasing population have been identified as key indicators of crop intensification and the non-judicious use of synthetic chemicals [1]. For instance, rather than using fertilizers containing a balanced mix of major soil nutrients, it is not uncommon for high levels of fertilizers containing only nitrogen $(\mathrm{N})$ to be applied to land as they are often cheaper. This has resulted in detrimental effects on the environment, such as nitrogen leaching to groundwater [2], and increased greenhouse gas emissions. The use of organic amendments (e.g., farm manure, compost and mulch) as alternatives to synthetic fertilizers can reduce $\mathrm{N}$ losses, improve $\mathrm{N}$ use efficiency, increase soil quality and improve $\mathrm{N}$ availability to plants [3,4]. Recently, biochar (BC) has received increasing attention as an organic amendment that can increase soil carbon sequestration [5], whilst providing the additional benefits of improved soil health and quality [6] and, most relevantly for this study, providing strong interaction with $\mathrm{N}$ fertilizer to reduce total nitrogen losses [7] and nitrate leaching [6,8-10], and may also act as a slow-release $\mathrm{N}$ fertilizer as recently reported by Kammann et al. [11] and Haider et al. [12].

Wheat production is under threat in South Asian countries like Pakistan due to increasingly extreme weather patterns resulting in extended dry spells and intensive rainfall events. The increased frequency of these events has been globally reported with climactic models suggesting that they will become increasingly common [13]. Variable high temperatures during grain formation, combined with low soil fertility and organic matter (OM), have also represented significant constraints to grain production in recent years $[14,15]$. Furthermore, warmer temperatures accelerate phenological development [16], resulting in low biomass yield due to less radiation interception and nutrient uptake, both of which serve to reduce crop yield [17]. Increased temperatures are forecast across arid regions [18], therefore, more $\mathrm{N}$ would be expected to be lost from the soil profile, particularly where $\mathrm{N}$ inputs remain unchanged. Nitrogen is an essential nutrient and a restrictive factor with regard to the productivity of major cereal crops [19]. The wheat crop yield depends on efficient nitrogen $(\mathrm{N})$ use to achieve higher yields [20]. Thus, it is essential for the nitrogen supply to be replenished in order to maintain or increase crop yield [21].

The potential of biochar amendments to influence nitrogen dynamics in agricultural soils under different climatic conditions has been reported [9,22]. Nitrogen cycling and transformation processes such as immobilization, fixation and mineralization are all reportedly influenced by the biochar application [23]. Biochar can also significantly minimize the leaching of $\mathrm{NO}_{3}{ }^{-}$and $\mathrm{NH}_{4}{ }^{+}$[6], lower the mineralization rate of organic $\mathrm{N}$ and reduce $\mathrm{N}_{2} \mathrm{O}$ emissions from a soil [24]. It has recently been reported that a combined application of synthetically developed controlled-release $\mathrm{N}$, normal urea fertilizer and biochar resulted in enhanced fertilizer use efficiency and increased rice yield compared to normal urea or controlled release $\mathrm{N}$ fertilizer over a three-year field study [25]. It was also found that biochar particles could capture mineral nitrogen during normal cropping for three years under temperate field conditions, although no yield improvements were observed $[9,10]$. When the biochar particles from the study were considered as an $\mathrm{N}$ source and compared to synthetic $\mathrm{N}$ sources under controlled conditions, the plant availability of the $\mathrm{N}$ captured by the biochar particles was found to be equal to that of the synthetic $\mathrm{N}$ [12]. These studies suggest that one way to improve $\mathrm{N}$ utilization may be to develop advanced approaches which utilize the nutrient retention capabilities of biochar, thus ensuring that $\mathrm{N}$ fertilizers can be supplied in a targeted way. 
The use of biofertilizers has been the subject of increasing research attention in the wake of increasing climate change issues and a drive to limit the use of synthetic $\mathrm{N}$ fertilizer in agriculture to reduce gaseous $\mathrm{N}$ losses $[26,27]$. Biofertilizers comprise a mixture of plant growth-promoting rhizobacteria [28] or arbuscular mycorrhizal fungi [29]. These organisms interact symbiotically with plant root systems improving stress tolerance and nutrient availability [30]. Moreover, Azospirillum and Azotobacter can also improve plant roots through adventitious root initiation via auxins exchange and root hair development [31,32]. Dal Cortivo et al. [27] reported that biofertilizers (including rhizobacteria and mycorrhizal fungi) can significantly improve small grain crop growth, nitrogen uptake and yield. Biochar and plant-growth-promoting biofertilizers may be used as a strategy to solubilize and improve nutrient availability to crops under arid conditions [33]. Arabi et al. [34] reported a significant (51\%) yield improvement in a soybean crop with combined biochar and bio-fertilizer application compared to no fertilizer. This highlights the potential for using organic resources to improve soil fertility and crop yield.

The study herein aimed to examine the chemical and biological enhancement effects of biochar on wheat growth and yield. Wheat was chosen as a test crop due to its being integral to Pakistan's food security and agricultural profitability/economic security. We hypothesized that: (a) Urea-N loaded onto biochar may serve as biochar-based slow-release $\mathrm{N}$ fertilizer which could improve plant-N availability (Haider et al., 2015; 2020). (b) The combined application of biochar and biofertilizers with low $\mathrm{N}$ application may improve soil-N transformation and improve plant availability, thereby improving crop growth and yield. The major objectives were to: (i) identify the most effective treatment combination of biochar, biofertilizer and $\mathrm{N}$ dose for arid wheat production. (ii) Improve soil carbon sequestration without compromising the farmer's profitability, as demonstrated economic benefits are more likely to be accepted in society and increase the chance of uptake.

\section{Materials and Methods}

\subsection{Experimental Site and Environmental Conditions}

A field experiment was carried out in Multan, the South-Punjab region of Pakistan, at $30.1598^{\circ} \mathrm{N}, 71.4502^{\circ} \mathrm{E}$; altitude $129 \mathrm{~m}$ (Figure 1 ). The study site falls under the country's arid subtropical region, with an annual average temperature of $32.6^{\circ} \mathrm{C}$ and average annual precipitation of $186.8 \mathrm{~mm}$. The diurnal variations observed in the study area fluctuated, with average air temperature varying from $26-49{ }^{\circ} \mathrm{C}$ and $4-23{ }^{\circ} \mathrm{C}$ throughout summer and winter periods, respectively. The maximum rainfall was recorded during the monsoon season (July and August) and was extremely varied. There was very little rainfall during the winter season, which meant that typical crop water demands were not met. The regular values of minimum (Tmin), maximum (Tmax), sunshine hours, growing degree days (GDDs) (above a specific threshold temperature and rainfall) observed throughout the study period are presented in Supplementary Materials Figure S1.

The research area was located between the rivers Sutlej (having water only under flood conditions since the 1960s) in the district Bahawalpur and the River Chenab (flowing freely throughout the year) in district Muzaffar Garh. The soil was silt loam in texture, river alluvium, brown, moderately calcareous, weakly structured, hyperthermic, Fluventic Haplocambic, Ochric epipedon and cambic subsurface horizons were present (Miani Soil Series) The soil was low in organic matter $(0.78 \%)$ which varied between different soil horizons $(0.10-0.40 \%)$ and was deficient in organic $\mathrm{N}(0.05 \%)$, available phosphorus $\left(7.90 \mathrm{mg} \mathrm{kg}^{-1}\right)$ and available potassium $\left(2.40 \mathrm{mg} \mathrm{kg}^{-1}\right)$ in the upper layer $(\leq 30 \mathrm{~cm})$. 


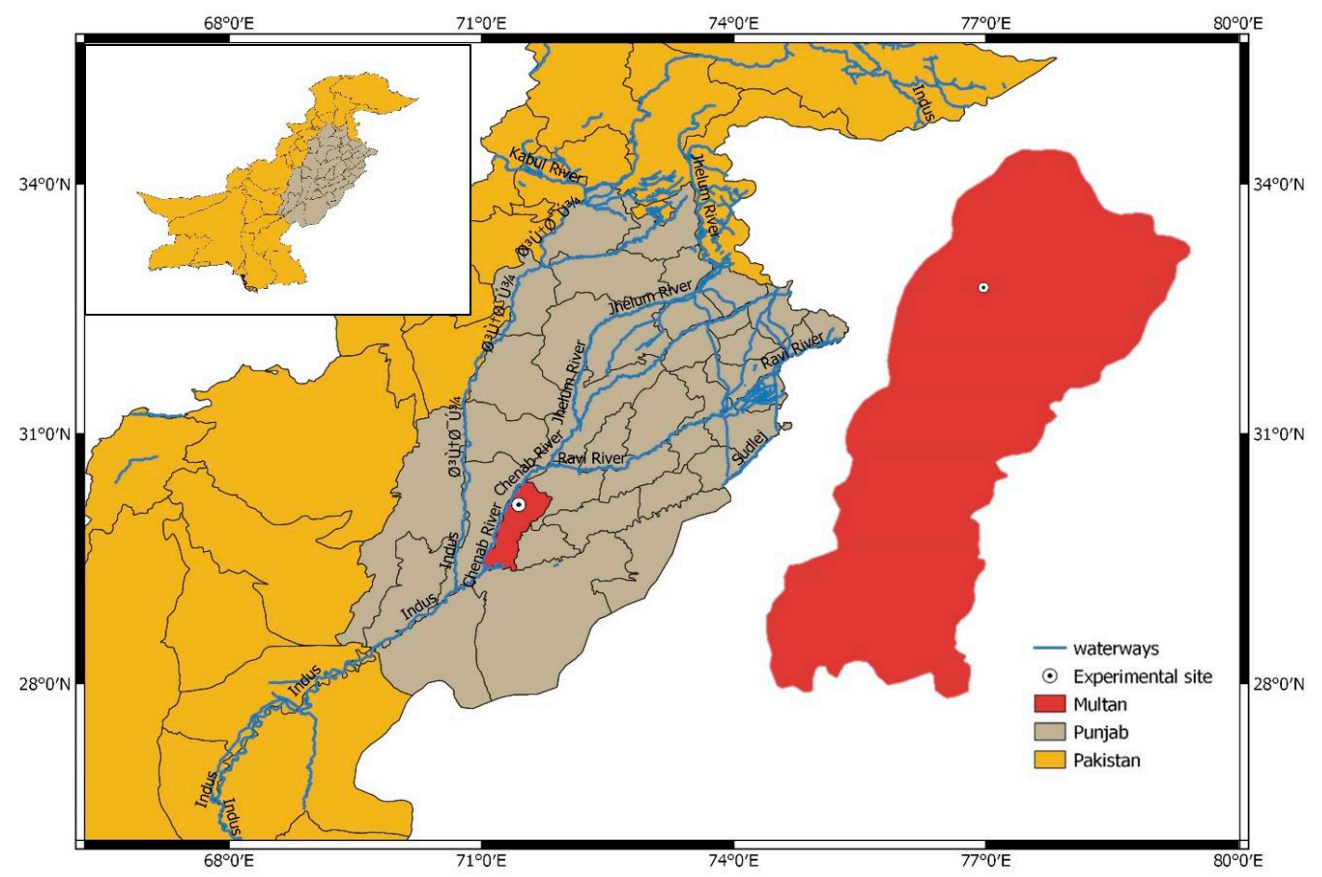

Figure 1. Location of the study area in South Punjab, Pakistan.

\subsection{Biochar Production and Characterization}

Biochar was produced from a cotton stalk feedstock which was collected from the experimental station of the University of Agriculture, Multan. The kon-tiki Flame Curtain Pyrolysis technique [35] was used to produce biochar at an approximate temperature of $500{ }^{\circ} \mathrm{C}$. The physicochemical properties of the biochar product were analyzed by a contract research laboratory (Eurofins, Hamburg, Germany) and are reported in Table 1.

Table 1. Physicochemical properties of cotton stalk biochar produced by the kon-tiki flame curtain pyrolysis technique. Analysis conducted by Eurofins, Hamburg, Germany.

\begin{tabular}{ccc}
\hline Parameters & Unit & Value \\
\hline Ash content $\left(550^{\circ} \mathrm{C}\right)$ & $\%(w / w)$ & 35.4 \\
Hydrogen & $\%(w / w)$ & 0.7 \\
Carbon & $\%(w / w)$ & 54.5 \\
Total Nitrogen & $\%(w / w)$ & 0.79 \\
Oxygen & $\%(w / w)$ & 9.1 \\
Carbon (organic) & $\%(w / w)$ & 53.4 \\
pH in CaCl & & 9.6 \\
Conductivity & $\mu \mathrm{S} / \mathrm{cm}$ & 6460 \\
\hline
\end{tabular}

\subsection{Experimental Details and Crop Management Practices}

The field experiment was conducted at the experimental station of Muhammad Nawaz Sharif (MNS) University of Agriculture Multan, Pakistan. The soil was plowed 3 times using a tractor-mounted plow and then planked to prepare the experimental plots. The experimental plots (length $\times$ width, $\mathrm{L}=8, \mathrm{~W}=6 ; 48 \mathrm{~m}^{2}$ ) were arranged after land leveling with a distance of $1.5 \mathrm{~m}$ between experimental units. Experimental treatments comprised: (i) A full nitrogen dose recommended for wheat in the region $\left(104 \mathrm{~kg} \mathrm{~N} \mathrm{ha}^{-1}\right)$ as a positive control. (ii) A half nitrogen dose $\left(52 \mathrm{~kg} \mathrm{~N} \mathrm{ha}^{-1}\right)$. (iii) A half nitrogen dose (52 $\mathrm{kg} \mathrm{N} \mathrm{ha}^{-1}$ ) + biofertilizer (bio-power at $4.94 \mathrm{~kg} \mathrm{ha}^{-1}$; a commercially available biofertilizer from National Institute of Biotechnology and Genetic Engineering, Pakistan) as a soil mixture. (iv) A half nitrogen dose $\left(52 \mathrm{~kg} \mathrm{~N} \mathrm{ha}^{-1}\right)+$ biofertilizer as seed inoculation. (v) A full nitrogen dose $\left(104 \mathrm{~kg} \mathrm{~N} \mathrm{ha}^{-1}\right)+\operatorname{biochar}\left(5 \mathrm{t} \mathrm{ha}^{-1}\right)$ inoculated with 
biofertilizer $\left(4.94 \mathrm{~kg} \mathrm{ha}^{1}{ }^{1}\right)$. (vi) A full nitrogen dose $\left(104 \mathrm{~kg} \mathrm{~N} \mathrm{ha}^{-1}\right)$ loaded on biochar $\left(5 \mathrm{tha}^{-1}\right)+$ biofertilizer applied as a soil mixture.

A nutrient (urea) solution was prepared for the treatment of the biochar, which was equivalent to $50 \%$ of the water holding capacity of the biochar. The biochar was dipped into the nutrient solution and thoroughly mixed in a large container prior to addition to the experimental plots. A similar procedure was adopted for biofertilizer seed inoculation. For the biochar treatment with biofertilizer, no additional sugar was added because biochar itself has labile carbon for an initial energy source for microbes.

The experimental treatments were replicated four times and arranged in a randomized complete block design (RCBD, $6 \times 4 n=24)$. Wheat cultivar Ujala-2016 was sown at a $22.25 \mathrm{~cm}$ line-to-line distance with a hand drill at the seed rate of $150 \mathrm{~kg} \mathrm{ha}^{-1}$. The basal dose of $\mathrm{N}$ (Urea) (where not loaded on biochar to mimic conventional practice), total phosphorous (DAP) and potassium, as Sulfate of Potash, was applied at the time of seed-bed preparation. The remaining $\mathrm{N}$ was applied on two occasions, 25 days after sowing (DAS) and 50 DAS. Biochar was applied at $5 \mathrm{tha}^{-1}$ on a dry mass basis. Irrigation was performed throughout the experimental duration as per crop requirements and weather conditions.

\subsection{Growth, Development, Light Interception, Radiation Use Efficiency and Final Data Collection and Derivation}

To examine the growth and development throughout the study, half of each plot area was allocated for sampling at each growth phase, while the remaining half plot was maintained until the final harvest to record total biomass and grain yield production. Destructive plant sampling was performed at different growth stages for growth parameters. The total fresh weight and the fresh weight of its different plant components (leaves and stem) were determined. A sub-sample was dried in an oven from which total dry matter (TDM; $\mathrm{g} \mathrm{m}^{-2}$ ) was calculated at each harvest. A sub-sample of green leaf lamina was used to record leaf area using a leaf area meter (JVC Model TK-S310EG). Leaf area index (LAI) was then calculated as the leaf area ratio to the land area [36]. Leaf area duration (LAD) was estimated as $\left(\mathrm{LAI}_{1}+\mathrm{LAI}_{2}\right) \times\left(\mathrm{T}_{2}-\mathrm{T}_{1}\right) / 2$ [37]. Where $\mathrm{LAI}_{1}$ and $\mathrm{LAI}_{2}$ are leaf area indices at times $\mathrm{T}_{1}$ and $\mathrm{T}_{2}$, respectively. Crop growth rate (CGR) was calculated as $\left(\mathrm{W}_{2}-\mathrm{W}_{1}\right) /\left(\mathrm{T}_{2}-\mathrm{T}_{1}\right)$ [37]. Where $\mathrm{W}_{1}$ and $\mathrm{W}_{2}$ are the dry weights harvested at time $\mathrm{T}_{1}$ and $\mathrm{T}_{2}$, respectively. While all other growth analyses, including net assimilation rate (NAR), were calculated using classical growth analysis techniques following the standard methods [37-39]. At maturity, ten plants from each treatment were randomly selected and yield components were recorded. At physical maturity, the crop was harvested from each experimental plot, and the final yield was converted to $\mathrm{kg} \mathrm{ha}^{-1}$.

The fraction of radiation intercepted/absorbed (Fi) by the green surfaces of the crop canopy was calculated from the specific interval, which started at sowing for each plot, using measurements of the LAI and the exponential model [1- exp $(-\mathrm{k} \times \mathrm{LAI})]$ [40]. Where $\mathrm{k}$ is a coefficient for total solar radiation equal to 0.46 [41]. This was calculated from the regression line's slope between $\ln (1 \times \mathrm{Fi})$ and LAI $[42,43]$. The amount of intercepted light $(\mathrm{Sa})$ was determined by multiplying Fi with incident PAR (Si) during the season as; $S a=F i \times S i$. The data of the incident and transmitted PAR (above and below the canopy) was recorded using a Sun Scan Canopy Analysis System (Delta-T Devices, UK). Measurements started after crop stand establishment and continued until crop maturity, while data was recorded between 12:00 and 13:00 h. The daily total incident solar radiation (SR) was calculated using Angstrom's formula [44]. The total PAR intercepted by the crop was calculated by multiplying Fi with $50 \%$ of incident radiation [45]. Radiation use efficiency for TDM $\left(R U E_{T D M}\right)$ and grain yield $\left(R U E_{G Y}\right)$ were calculated using Equations (1) and (2) [46].

$$
\begin{aligned}
& R U E_{T D M}=T D M / \sum S a \\
& R U E_{G Y}=\text { Grain's Yield } / \sum S a
\end{aligned}
$$


Alternatively, radiation use efficiency was estimated by regressing yield against accumulated intercepted radiation [39].

The daily maximum air temperature (Tmax) and minimum temperature (Tmin) were used to calculate the thermal time (growing degree days, GDD) requirements above a threshold temperature $(T T)$ in terms of degrees days $(D D)$. Thermal time was calculated using the $D D$ as the difference between the daily mean temperature and the threshold temperature (TT) specific for the wheat crop (Equation (3)).

$$
\mathrm{DD}\left({ }^{\circ} \mathrm{C} \text { days }=\sum_{i=d h}^{i=d s}\left[\left\{\frac{T \text { max }+ \text { Tmin }}{2}\right\}-T T\right]\right.
$$

where, $D D\left({ }^{\circ} \mathrm{C}\right.$ days $)$ accretion is the accumulative degrees days for specific phenophase, " $d s$ " is the date of sowing, " $d h$ " is the date of harvest, TT is threshold temperature which was considered as $4^{\circ} \mathrm{C}$ for the wheat crop to compute the thermal time [47]. For instance, if $[(T \max +T \min ) / 2]<T T$, or $[(\operatorname{Tmax}+T \min ) / 2]=T T$, then $D D$ was considered equal to zero.

\subsection{Soil and Plant Nitrogen Analysis}

Three samples from each plot were thoroughly mixed to homogenize. Soil samples were packed in plastic bags, stored at $4{ }^{\circ} \mathrm{C}$ and later dried at $60{ }^{\circ} \mathrm{C}$ prior to analysis. Soil mineral nitrogen $\left(\mathrm{NO}_{3}{ }^{-}\right.$and $\left.\mathrm{NH}_{4}{ }^{+}\right)$determination was performed by extracting the dried soil samples using $2 \mathrm{M} \mathrm{KCl} \mathrm{[48]} \mathrm{followed} \mathrm{by} \mathrm{determination} \mathrm{using} \mathrm{a} \mathrm{spectrophotometer.}$ Briefly, $40 \mathrm{~mL} 2 \mathrm{M} \mathrm{KCl}$ was added to $10 \mathrm{~g}$ of soil and shaken for $1 \mathrm{~h}$ at $100 \mathrm{rpm}$ and filtered. The filtrate was then analyzed for nitrate and ammonium concentrations following [49] and [50], respectively.

The plant nitrogen concentrations were determined from oven-dried plant samples $\left(65^{\circ} \mathrm{C}\right.$ for $48 \mathrm{~h}$ ), which were ground using a mechanical grinder and stored in plastic bags. Plant samples $(0.33 \mathrm{~g})$ were digested in a solution of $5 \mathrm{~mL}$ of sulfuric acid $\left(\mathrm{H}_{2} \mathrm{SO}_{4}\right)$ and $2 \mathrm{~mL}$ sodium hydroxide $(\mathrm{NaOH})$ on a block digester until colorless. A $0.2 \mathrm{~mL}$ sample of the digestant was used to determine the $\mathrm{N}$ concentration as outlined in [49].

\subsection{Statistical Analysis}

Analysis of variance (ANOVA) for all response variables was analyzed based on a general linear mixed model (GLM) using SAS version 9.4 [51]. The effects of each treatment were assessed separately and collectively for all studied parameters. Further, Tukey's Honest Significant Difference (HSD) test for mean comparison was used to distinguish any differences between treatment means and was considered significant where $p \leq 0.05$. To identify any relationship between different growth and yield parameters, simple and multiple linear regressions were used according to the formula model in Equation (4).

$$
\hat{Y}=\hat{\beta}_{0}+\hat{\beta}_{1} X_{1}+\hat{\beta}_{2} X_{2}+\hat{\beta}_{3} X_{3}+\ldots+\hat{\beta}_{\mathrm{n}} X_{n}
$$

The multiple linear regression model was adjusted stepwise by "backward elimination" (successive elimination of independent variables). Statistical indices such as root mean square error (RMSE) and coefficient of determination $\left(\mathrm{R}^{2}\right)$ were computed for results accuracy assessment. Root mean square error (RMSE) was used to determine statistical differences between the observed and modeled parameters. This was computed using Equation (5) to determine the predictability degree. Here $n$ denotes the observation number used for comparisons, $X_{S}$ is the modeled variables studied, while $X o$ is the observed one used in Equation (5).

$$
R M S E=\sqrt{\left[\frac{\sum_{i=1}^{n}\left(X_{S}-X_{o}\right)^{2}}{n}\right]}
$$


Results accuracy and model performance was also evaluated by the coefficient of determination $\left(\mathrm{R}^{2}\right)$ calculated using Equation (6), where $O_{i}$ is the $i$ th observation is recorded, $M^{\prime}{ }_{i}$ is the $i$ th modeled and $\bar{O}$ is the average observation of recorded variables.

$$
\mathrm{R}^{2}=1-\left[\frac{\sum_{i}\left(O_{i}-M_{i}\right)^{2}}{\sum_{i}\left(O_{i}-\bar{O}\right)^{2}}\right], 0 \leq d \leq 1
$$

\section{Results}

\subsection{Crop Growth and Development}

Overall, the application of chemically enhanced biochar, or co-application with biofertilizer as a soil amendment, positively influenced the wheat growth and development for where a half dose of $\mathrm{N}+$ biofertilizer was applied. However, there was no significant difference between the full $\mathrm{N}$ dose either alone (conventional fertilizer application, $\mathrm{T}-\mathrm{i}$ ) or as biochemically enhanced biochar (Tv and T-iv) with regard to peak leaf area index of wheat at 90 days after sowing (Figure 2). The half dose of $\mathrm{N}$ application, both with and without biopower, produced significantly lower LAI at 90 DAS compared to the conventional full $\mathrm{N}$ dose with biochemically enhanced biochar application. Treatment vi (104 $\mathrm{kg} \mathrm{N} \mathrm{ha}^{-1}$ loaded on biochar + biofertilizer used as soil mixture) produced the highest LAI $(1.86,4.63$, 2.92) at different time-periods (64, 90 and 124 DAS, respectively). The effect of nitrogen and biochar application on temporal variations in LAI is presented in Figure 2.

The treatment vi (104 $\mathrm{kg} \mathrm{N}$ ha $^{-1}$ loaded on biochar + biofertilizer used as soil mixture) produced the highest dry matter yield $\left(192,908,1195,1260 \mathrm{~g} \mathrm{~m}^{-2}\right)$ at all time periods (64, 90 and 124 DAS, respectively). The minimum TDM $\left(114,602,759\right.$ and $\left.821 \mathrm{~g} \mathrm{~m}^{-2}\right)$ was produced by the treatment ii (52 kg N ha ${ }^{-1}$ applied singularly) (Figure 2). Wheat crop canopy development (LAI) was improved by applying nitrogen in combination with biochar, leading to a higher total intercepted photosynthetically active radiation (TIPAR). A strong positive association was found between LAI and lead area duration (LAD) with the TIPAR an indicator of the beneficial effect of combined application of biochar on wheat crop growth and light interception (Figure 3). Similar trends were observed for CGR, treatment vi (104 kg N ha ${ }^{-1}$ loaded on biochar + biofertilizer as a soil mixture) produced higher CGR values $\left(15.56,14.36,1.92 \mathrm{~g} \mathrm{~m}^{-2}\right.$ day $\left.^{-1}\right)$ for temporal analysis $(64,78$ and 88 DAS, respectively) in the wheat crop (Figure 2).

In general, the addition of $\mathrm{N}$ improved growth attributes of the wheat crop, as with LAI, the time intercepted PAR was attained due to a larger canopy and higher LAI due to the application of higher $\mathrm{N}$ application $\left(104 \mathrm{~kg} \mathrm{~N} \mathrm{ha}^{-1}\right)$. Furthermore, biochar also promoted crop growth and attained a higher intercepted PAR $\left(426.33 \mathrm{MJm}^{-2}\right)$ when treatment vi (104 $\mathrm{kg} \mathrm{N} \mathrm{ha}^{-1}$ loaded on biochar and additionally bio-fertilizer) was applied in soil rather than low $\mathrm{N}$ (52 $\mathrm{kg} \mathrm{N} \mathrm{ha}^{-1}$ ) application as compared with recommended (104 $\left.\mathrm{kg} \mathrm{N} \mathrm{ha}^{-1}\right)$. Lower IPAR was attained under treatment ii (half $\mathrm{N}$ dose $52 \mathrm{~kg} \mathrm{~N}$ ha $^{-1}$ ), suggesting that $\mathrm{N}$ has a direct relationship with crop growth to develop the crop canopy. Even though biochar has a positive and promoting role in crop canopy parameters such as LAI, it was found here to be too non-significant. However, biochar treatments such as treatment vi (104 kg N ha ${ }^{-1}$ loaded on biochar + biofertilizer as a soil mixture) gave the highest values but this was not statistically significant $(p>0.05)$ in the treatments where only $\mathrm{N}$ fertilizer was applied. 

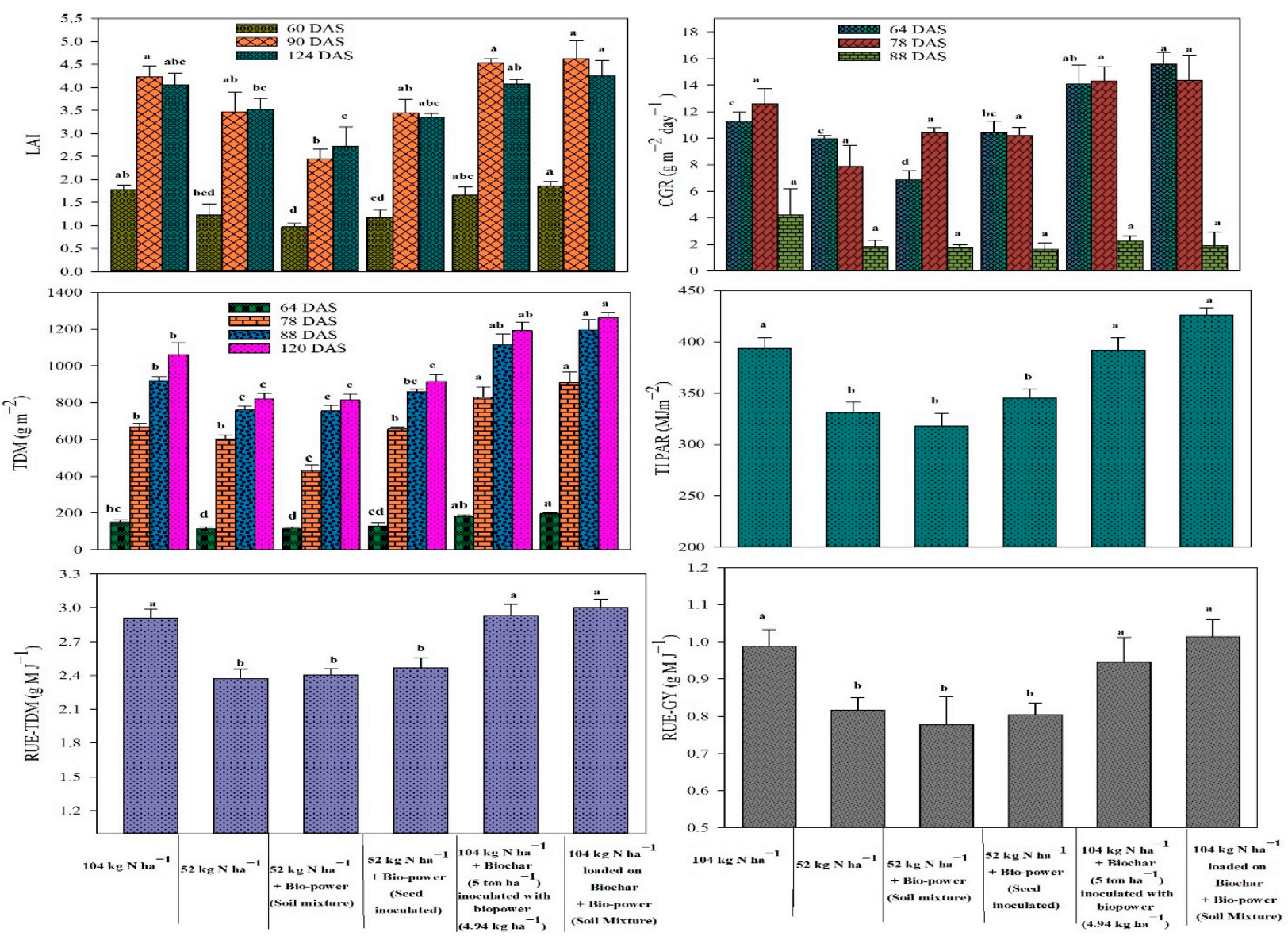

Figure 2. Effect of co-application of BC and nitrogen fertilizer on the leaf area index (LAI), crop growth rate (CGR), total dry matter (TDM), total intercepted PAR, radiation use efficiency for the total dry matter (RUE-TDM) and radiation use efficiency for grain yield (RUE-GY) at growth stages of wheat crop under arid environmental conditions. * (Letters "a- $\mathrm{d}$ " are to show the mean difference in different groups at $p \leq 0.05$ by Tuckey HSD test).

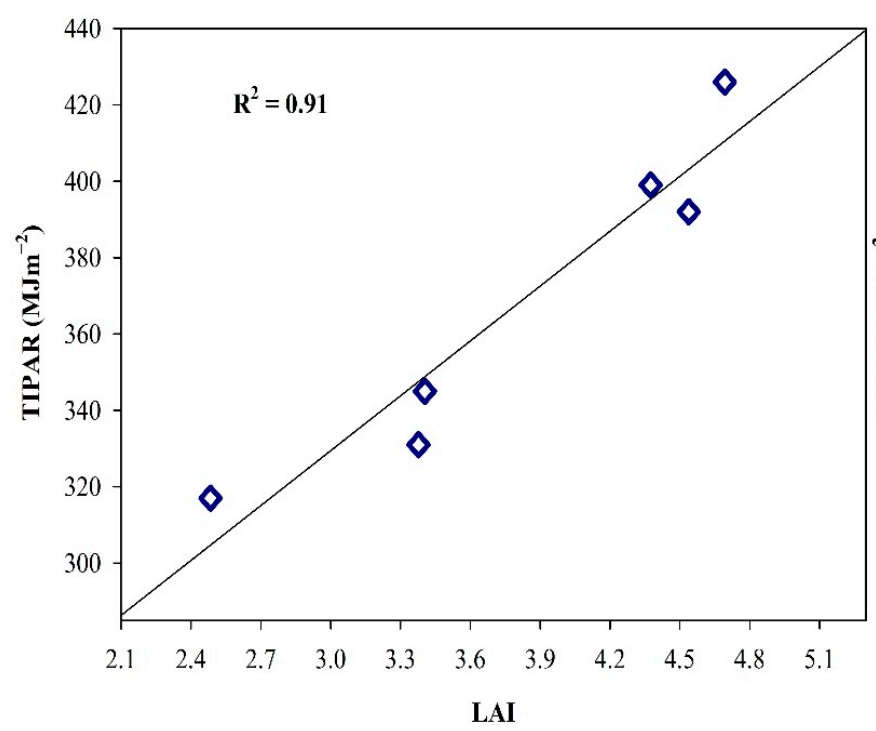

A

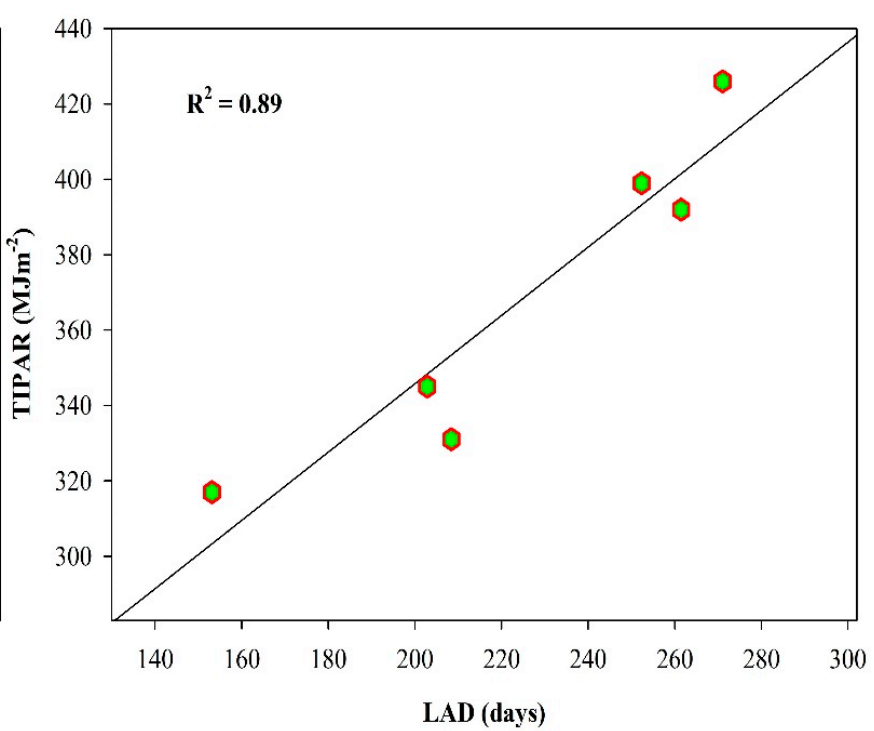

B

Figure 3. Relationship between peak LAI (A) and cumulative lead area duration (B) with total intercepted photosynthetically active radiation (TIPAR) for the wheat crop. 
The RUE trend for TDM and grain yield (GY) was observed similar to that of IPAR. The results revealed a positive relationship with a high-value determination coefficient $\left(R^{2}=0.94\right)$ between TIPAR and TDM and CGR, which showed a dependency of biomass production and growth rate for light interception through the wheat crop canopy (Figures 3 and 4). Treatment vi (biochar application rate $\left(5 \mathrm{tha}^{-1}\right)$ loaded with nitrogen and added in combination with soil mixture bio-fertilizer) attained the highest RUE for TDM and GY $\left(3.0,1.02 \mathrm{~g} \mathrm{MJ}^{-1}\right)$ production compared to the other treatments and the positive control with although this was not statistically significant $(p>0.05)$ (Figure 2). A lower RUE for TDM and grain yield was attained for treatment ii (52 $\mathrm{kg} \mathrm{N} \mathrm{ha}^{-1}$ application). Nitrogen has a strong and positive association with growth, especially dry matter accumulation. However, biochar serves to promote this further through a positive relationship with biomass and TDM. The highest NAR $\left(4.40,4.14\right.$ and $\left.3.71 \mathrm{~g} \mathrm{dm}^{-2} \mathrm{day}^{-1}\right)$ was produced by the full $\mathrm{N}$ fertilizer application (104 $\mathrm{kg} \mathrm{N} \mathrm{ha}^{-1}$ either loaded on biochar or applied in conventional method). While the lowest NAR $\left(2.89,2.91 \mathrm{gdm}^{-2} \mathrm{day}^{-1}\right)$ were produced where only a half $\mathrm{N}$ fertilizer applied (52 $\mathrm{kg} \mathrm{N} \mathrm{ha}^{-1}$ ) (Figure 4). Supporting the fact that NAR depends on $\mathrm{N}$ fertilization and increases by the $\mathrm{N}$ application.
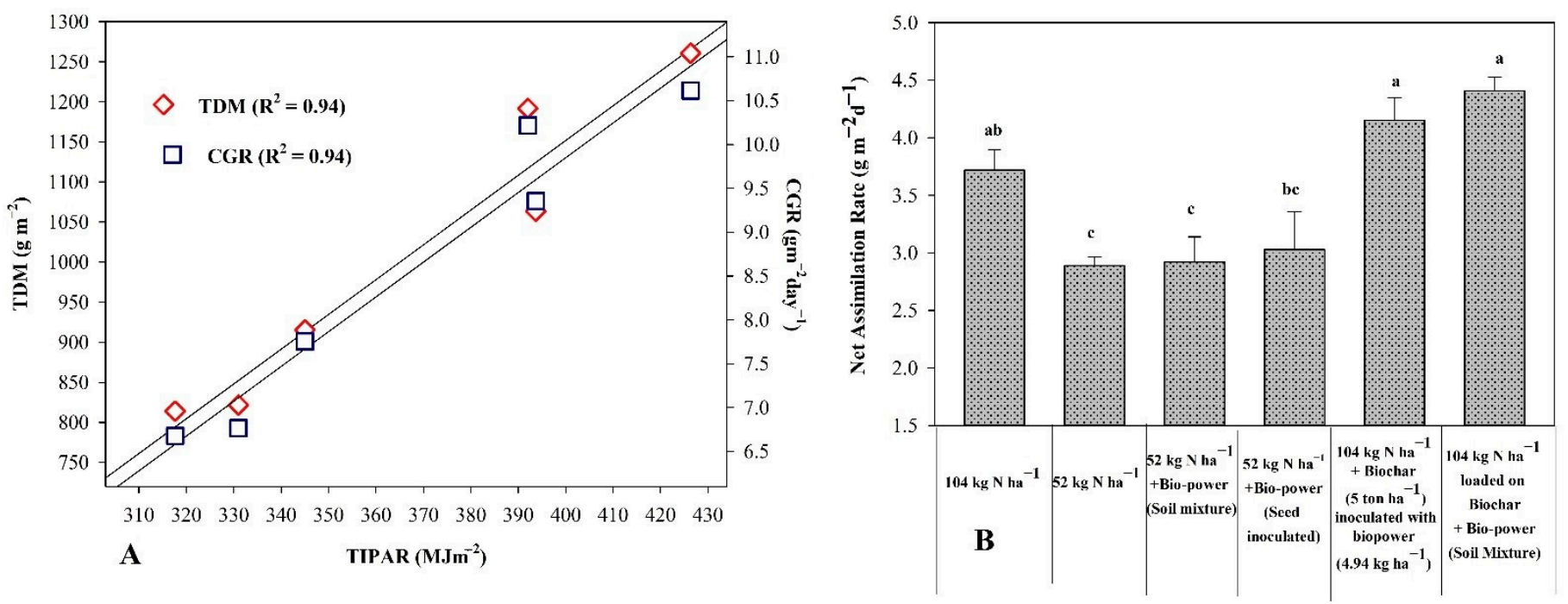

Figure 4. Relationship between total intercepted photosynthetically active radiation (TIPAR) with TDM and mean CGR of the wheat crop. * (Letters "a-c" are to show the mean difference in different groups at $p \leq 0.05$ by Tuckey HSD test).

\subsection{Agronomic Yield Attributes and Grain Yield}

The results of yield contributing factors, biological and grain yield of wheat are presented in Figures 5 and 6. The full $\mathrm{N}$ dose of $\mathrm{N}$ fertilizer application either with or without biochar significantly improved ( $8 \%$ ) the productive tillers compared to the half dose of $\mathrm{N}$ fertilizer. Interestingly, the second most effective treatment for improving the number of productive tillers $(p \leq 0.05)$ was treatment $\mathrm{v}\left(104 \mathrm{~kg} \mathrm{~N} \mathrm{ha}^{-1}\right.$ along with inoculated biochar), which increased the productivity by $7 \%$. Plant height increased by $4 \%$ for treatment vi (104 $\mathrm{kg} \mathrm{N} \mathrm{ha}^{-1}$ loaded on biochar with biofertilizer as a soil mixture) compared to the conventional full $\mathrm{N}$ dose or half $\mathrm{N}$ fertilizer applications (treatments $\mathrm{i}$ and ii). 


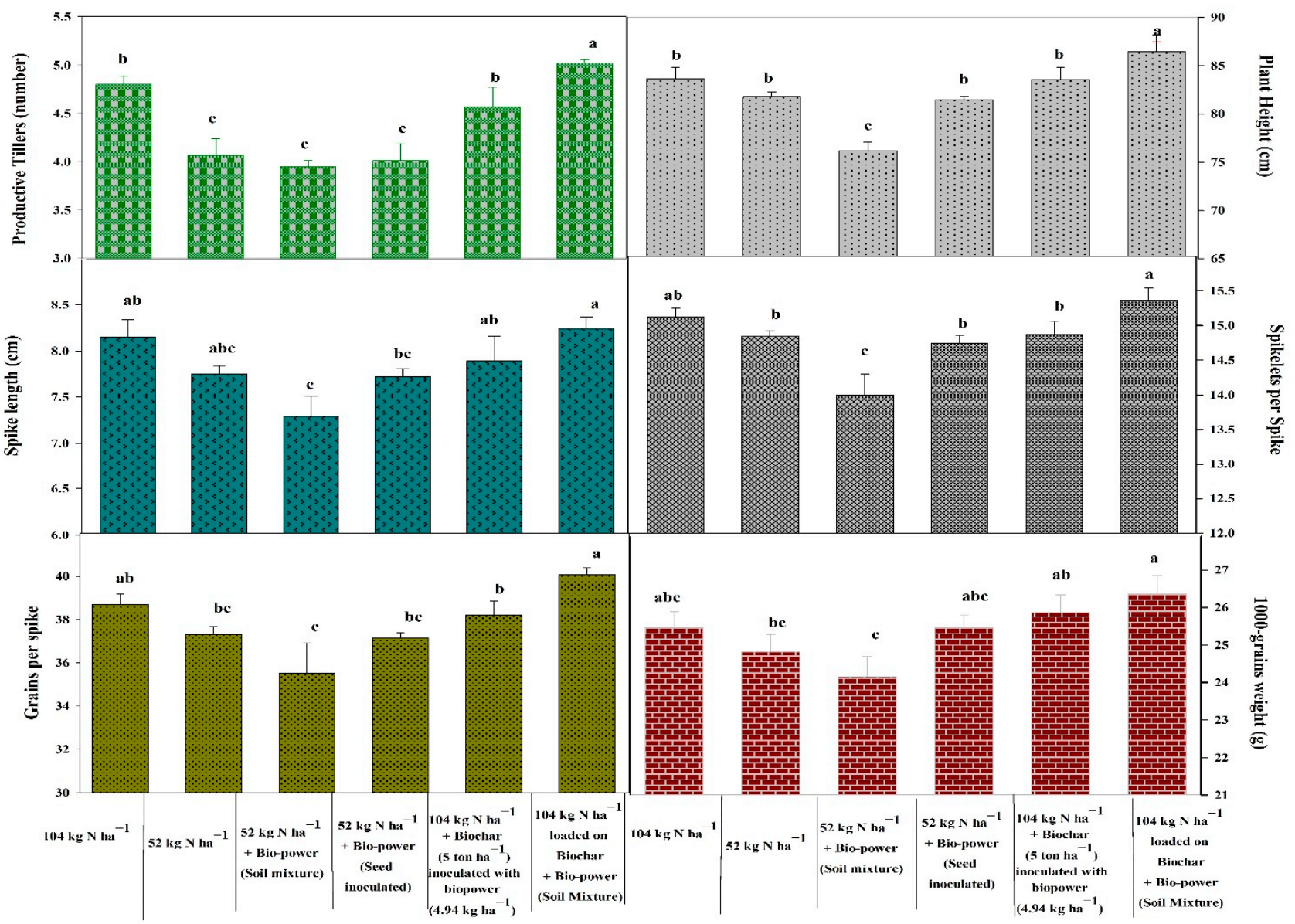

Figure 5. Effect of different nitrogen levels and the combination of $\mathrm{N}$ with BC on yield components of the wheat crop in arid environmental conditions. * (Letters " $\mathrm{a}-\mathrm{c}$ " are to show the mean difference in different groups at $p \leq 0.05$ by Tuckey HSD test).

Treatment vi (104 $\mathrm{kg} \mathrm{N} \mathrm{h}^{-1}$ loaded on biochar and biofertilizer as a mixed soil), produced the highest spike length $(8.24 \mathrm{~cm})$ compared to full and half dose of sole $\mathrm{N}$ applications (treatments i and ii). The maximum number of spikelets per spike $(15.62,6 \%$ higher over control) was produced by the application of treatment vi $\left(104 \mathrm{~kg} \mathrm{~N} \mathrm{ha}^{-1}\right.$ loaded on biochar and biofertilizer as a soil mixture) compared to the rest of the treatments (Figure 5). The maximum grain number (40.67) was produced by applying treatment vi (104 $\mathrm{kg} \mathrm{N} \mathrm{ha}^{-1}$ loaded on biochar and biofertilizer as a soil mixture). The highest 1000 -grains weight $(26.23 \mathrm{~g}$, $4 \%$ greater than control) was produced by the treatment vi (104 $\mathrm{kg} \mathrm{N} \mathrm{ha}^{-1}$ loaded on biochar and biofertilizer as a soil mixture). Treatment vi (104 $\mathrm{kg} \mathrm{N} \mathrm{ha}^{-1}$ loaded on biochar and biofertilizer as a soil mixture) produced the maximum grain yield ( $2353 \mathrm{~kg} \mathrm{ha}^{-1}$ ), which is greater than control (conventional $\mathrm{N}$ fertilization) (Figure 6). The lowest values in all growth, yield, and yield components were found in applications with half $\mathrm{N}$ fertilizer doses $\left(52 \mathrm{~kg} \mathrm{~N}^{-1}\right)$. As wheat crop growth has a positive association and is dependent on light interception and RUE, the GY also showed a positive relationship with TIPAR having a higher coefficient of determination $\left(R^{2}=0.94\right)$ for the studied treatments (Figure 7). 


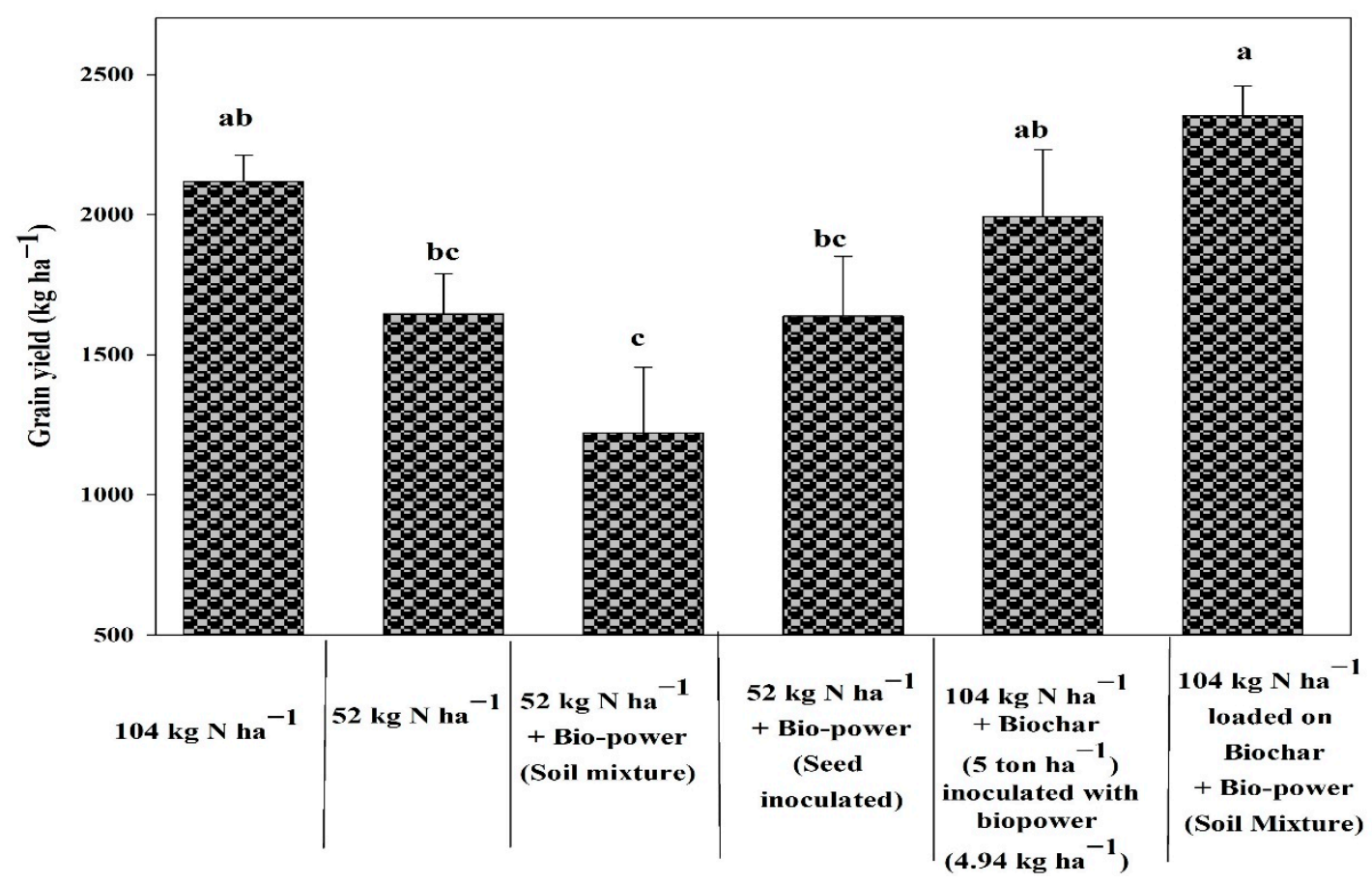

Figure 6. Effect of different nitrogen levels and the combination of $\mathrm{N}$ with BC on NAR at (peak growth stage, $80 \mathrm{DAS}$ ) and grain yield wheat crop in arid environmental conditions. * (Letters "a-c" are to show the mean difference in different groups at $p \leq 0.05$ by Tuckey HSD test).
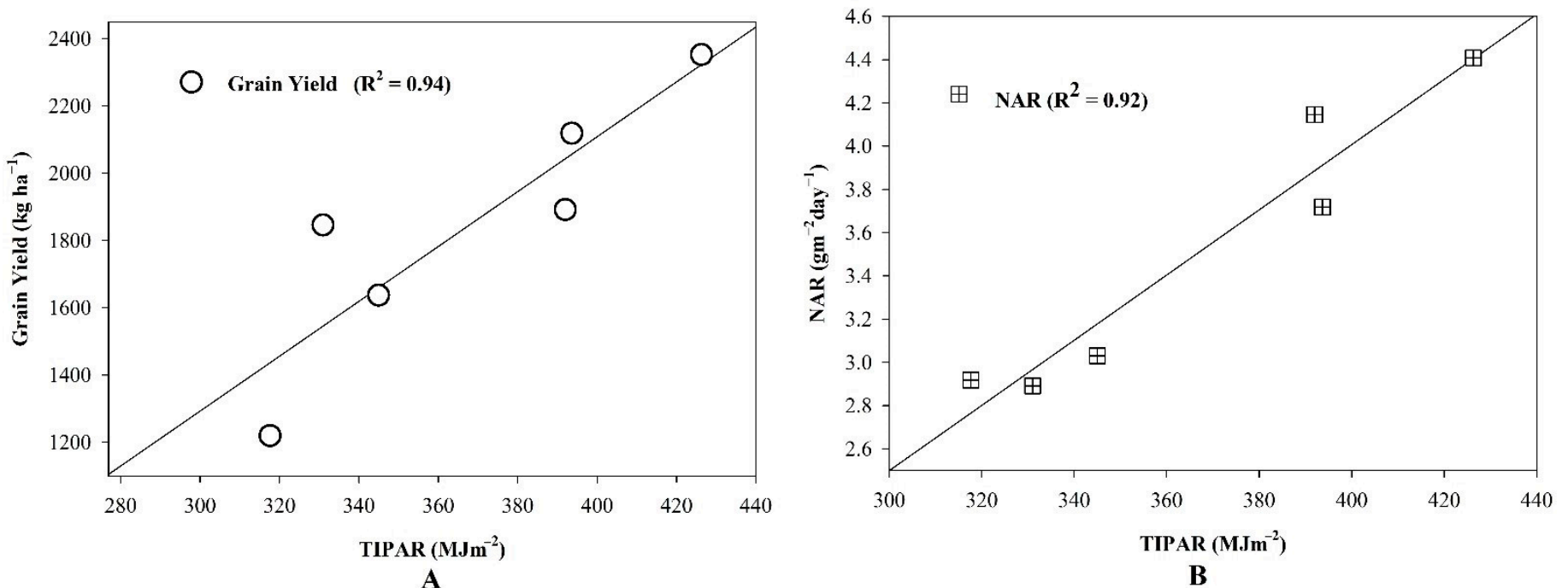

Figure 7. Relationship between total intercepted photosynthetically active radiation (TIPAR) and grain production and NAR of the wheat crop.

\subsection{The Soil Mineral Nitrogen $\left(\mathrm{NH}_{4}{ }^{+}, \mathrm{NO}_{3}{ }^{-}\right)$during the Crop Growth Period and Plant $\mathrm{N}$ at Harvest}

The nitrogen content of wheat straw and grain is presented in Figure 8. The treatment vi achieved the highest nitrogen content $\left(26.63 \mathrm{mg} \mathrm{kg}^{-1}\right)$ in wheat straw. The highest nitrogen uptake in the grain was observed in treatments vi and i (40.00 and $39.92 \mathrm{mg} \mathrm{kg}^{-1}$, respectively). The half dose $\mathrm{N}$ application, either alone or biofertilizer, resulted in the lowest plant $\mathrm{N}$ content. 

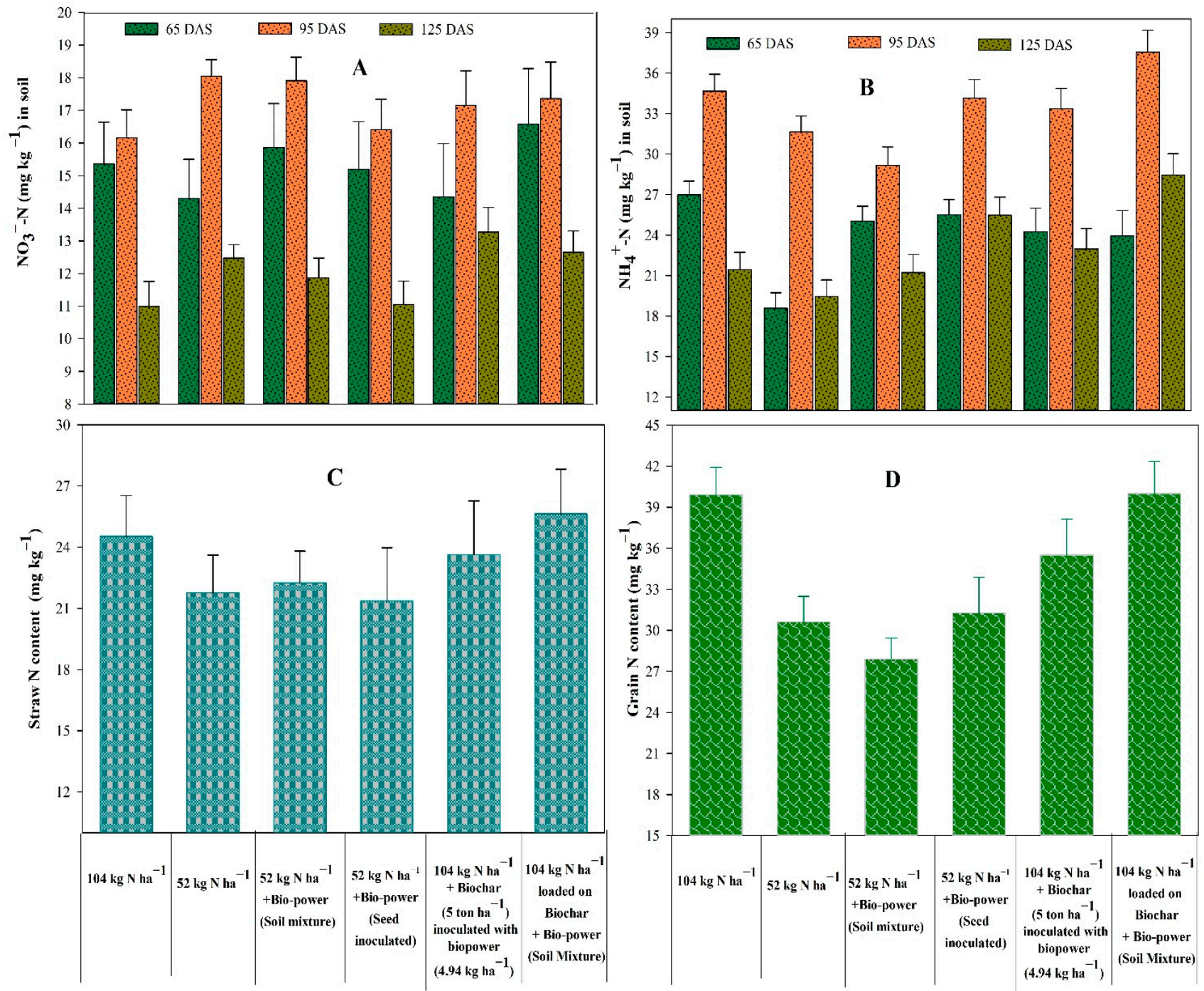

Figure 8. The effect of co-application of $\mathrm{BC}$ and nitrogen fertilizer on $\mathrm{NO}_{3}{ }^{-}$and $\mathrm{NH}_{4}{ }^{+}(65,95$ and $125 \mathrm{DAS})$ on soil (A,B), and wheat straw and grains $(\mathbf{C}, \mathbf{D})$ on wheat crop under arid environmental conditions.

The results of $\mathrm{NO}_{3}{ }^{-}-\mathrm{N}$ and $\mathrm{NH}_{4}{ }^{+}-\mathrm{N}$ concentrations in the soil during the wheat crop growing period are presented in Figure 8. During the initial 65-96 days after crop sowing, there was no significant effect of different soil mineral nitrogen treatments. However, a significantly higher $\mathrm{NH}_{4}{ }^{+}-\mathrm{N}$ was in treatment vi plots amended with $104 \mathrm{~kg} \mathrm{~N}^{-1}$ loaded on biochar applied and with biofertilizer as a soil mixture. A high $\mathrm{NO}_{3^{-}}-\mathrm{N}$ concentration (16.58 $\left.\mathrm{mg} \mathrm{kg}^{-1}, 17.35 \mathrm{mg} \mathrm{kg}^{-1}, 14.39 \mathrm{mg} \mathrm{kg}^{-1}\right)$ was present within the upper soil layer $(30 \mathrm{~cm})$ at $65,95,125 \mathrm{DAS}$, respectively, in treatment vi. Nitrate $\left(\mathrm{NO}_{3^{-}}-\mathrm{N}\right)$ retention in soils with treatments that included biochar were consistently higher $\left(15.35 \mathrm{mg} \mathrm{kg}^{-1}\right.$, $16.15 \mathrm{mg} \mathrm{kg}^{-1}, 11.98 \mathrm{mg} \mathrm{kg}^{-1}$ ) than in the control soil treatment $\mathrm{i}, \mathrm{N}$ fertilizer dose $\left(104 \mathrm{~kg} \mathrm{~N} \mathrm{ha}^{-1}\right)$.

\section{Discussion}

The present study was conducted in arid field conditions on a silt loam, calcareous and low organic matter soil. These coarse-textured soils of south Punjab Pakistan are characterized by high $\mathrm{N}$ losses via ammonia volatilization, surface run-off and nitrate leaching during heavy rainfall events or flood irrigation. Carbon-poor, less fertile tropical soils have been proposed in various studies to be potential hotspots for where biochar amendment may be used to enhance carbon sequestration and provide additional soil fertility benefits [50]. We therefore hypothesized that biochar use in south Punjab Pak- 
istan's calcareous soils might improve carbon sequestration and wheat productivity. Thus, biochar in combination with biofertilizer may improve soil health and crop yield under such conditions.

The application of biochar can be effective at rehabilitating degraded lands by improving the soil structure, nutrient- and water-holding capacity and soil carbon contents, leading to improvement in soil productivity [52]. A carbon-rich compound called charcoal is produced through a process known as pyrolysis and has a positive synergetic effect on beneficial microbial communities such as bacteria and fungi by providing habitats for improving soil health and crop yield [53-60]. The physicochemical properties of biochar are crucial in determining its functionality and impact on plant growth and soil health [61]. It was observed that biochar contains a high carbon-to-nitrogen ratio [62], making it stable against decomposition.

The plant response to biochar is varied and depends upon biomass used for producing biochar, soil type and plant species. There are interactions between biochar and added nitrogen, which may generate a considerable response to biochar and nitrogen in the soil and crops. Herein we observed statistically higher dry biomass with the application of a full fertilizer dose (104 $\mathrm{kg} \mathrm{N} \mathrm{ha}^{-1}$ ) either loaded on biochar or the application of biochar inoculated with biofertilizer. These results are consistent with literature reports [63], of a positive response of the wheat crop to biochar interaction with nitrogen fertilizer and biofertilizer. The addition of nitrogen fertilizer increased the soil nutrient status, total dry matter and associated components, i.e., shoot, leaves and grain. From these outcomes it was determined that there was nutrient limitation in soil without fertilization due to its low organic carbon and clay contents.

Additionally, increasing the nitrogen fertilizer application rate after sowing changed biomass allocation and decreased the leaf area proportion, root and shoot biomass, increasing grain weight with growing days. The addition of biochar combined with nitrogen and biofertilizer enhanced crop growth rate and total dry mass after the seventh week of the wheat crop growing season, which was due to interception of more photosynthetically active radiation and available soil nutrients accelerate plant growth and development. In this study, improved crop growth and yield response to co-application of nitrogen fertilizer, biochar and biofertilizer agree with the results of [64], who reported yield improvements had been observed in response to biochar amendments that were combined applications of commercial fertilizer. All agronomic and yield-related components are influenced through the sole two $\mathrm{N}$ application levels alone, although yield enhancement is reported in the following combined $\mathrm{N}$ with $\mathrm{BC}$ application. Crop responses to improved yield are likely due to $\mathrm{BC}$ alkaline nature and a rich carbon source with a slow release of nutrients.

Furthermore, positive effects of $\mathrm{BC}$ with $\mathrm{N}$ fertilizers are evident in many studies $[65,66]$. Biochar used as an organic amendment improved soil properties decreasing soil compaction, increasing water holding capacity, reducing nutrient losses and causing a considerable increase in nutrient use efficiency and crop yield improvement. This study explored the interaction between biochar and chemical fertilizer for different wheat growth stages and grain production. Soil amendments improves soil quality and productivity. In contrast to the study of [67], biochar application as a soil amendment improved the grain production during the short-term study, consistent with many other findings [68-70].

The present study was conducted under field conditions. Nitrogen losses might be possible due to a flood irrigation system. Biochar capacity of nutrient adsorption has limited nitrogen availability, particularly after nitrogen fertilizer in a short period study. Our study suggests that biochar amended soils improved $\mathrm{N}$ retention in the topsoil layer and reduced $\mathrm{NO}_{3}{ }^{-}$leaching. These results are inconsistent with other studies of $[6,8,71-85]$. Freshly produced biochar has a lower nitrogen content in comparison to aged biochar. Consequently, biochar amended soils reduced $\mathrm{NO}_{3}{ }^{-}$leaching, and increased extractable amounts of total $\mathrm{N}$, which is related to direct $\mathrm{NH}_{4}{ }^{+}$adsorption due to biochar having has a higher cation exchange capacity compared to anion exchange capacity. Here, significantly high $\mathrm{NO}_{3}{ }^{-}$retention was observed in topsoil amended with biochar shortly after the study 
began. This was due to the retention of capability of the biochar which reduced $\mathrm{N}$ leaching from the soil following $\mathrm{N}$ fertilization, additionally, soil and crop uptake of $\mathrm{N}$ continued as would be expected so less $\mathrm{N}$ was leached from the topsoil.

\section{Conclusions}

Nitrogen is an essential nutrient for ensuring proper wheat growth and acceptable yield. Losses of nitrogen fertilizer are higher under arid environmental conditions, thus having a detrimental impact on wheat growth within regions under these conditions. The results presented in this study demonstrate that the application of nitrogen-loaded biochar and biofertilizer as soil mixture significantly influenced crop growth and resulted in better crop yield. Furthermore, the application of nitrogen and biochar inoculated with biofertilizer treatment was shown to give a significantly higher yield compared to the rest of the treatments trialed. This reflects the treatment facilitating better nutrient uptake by the plants and reducing nitrogen loss through leaching.

It was determined that the inclusion of biochar in treatments resulted in better nitrogen retention in the nitrate form and reduced nitrate leaching and minimized nitrogen losses via enhanced retention. This study suggests that nitrogen loaded on biochar and biofertilizer used as soil mixture can synergize the positive effects of biochar application and nitrogen retention under an arid environmental condition in Pakistan. We, therefore, suggest that root zone application of biochar loaded with $\mathrm{N}$ fertilizer is a more effective approach to maintaining soil productivity. This study explored biochar as a potential nutrient carrier that may act as a slow-release fertilizer for wheat production and improved soil health Further work is needed to confirm whether the higher crop yield and improved soil health observed are as a result of the nitrate retention; to model the impact of improved biochar and nitrogen retention in projected future climate conditions, and to test whether these adaptation strategies would be beneficial for enhancing wheat production under future climate scenarios across the region.

Supplementary Materials: The following are available online at https:/ /www.mdpi.com/article/10 .3390 /su13115890/s1, Figure S1: Daily weather conditions (max. and min. air temperature, sunshine hours, rainfall and growing degree days (GDDs) calculated on a thresh hold temperature of $4{ }^{\circ} \mathrm{C}$ ) during wheat crop growing season.

Author Contributions: Conceptualization, Z.K., G.H. and M.H.u.R.; methodology, Z.K., G.H. and M.H.u.R.; software, G.H. and R.A.; validation, R.M.I., S.A. and G.H.; formal analysis, Z.K. and M.H.u.R.; investigation, Z.K. and M.H.u.R.; resources, G.H. and M.H.u.R.; data curation, Z.K., M.H.u.R., B.R. and R.I.; writing—original draft preparation, H.K.S., G.H., M.H.u.R., S.F., R.D., S.D., A.E.S. and A.B.; writing—review and editing, H.K.S., M.H.u.R., S.F., R.D., S.D., A.E.S. and A.B. All authors have read and agreed to the published version of the manuscript.

Funding: This work was supported by the Higher Education Commission Pakistan under Start-up Research grant no. 21-1678/SRGP/R\&D/HEC/2017. The current work was funded by Taif University Researchers Supporting Project number (TURSP-2020/295), Taif University, Taif, Saudi Arabia.

Institutional Review Board Statement: Not applicable.

Informed Consent Statement: Not applicable.

Data Availability Statement: Not applicable.

Acknowledgments: We are highly thankful to Rahul Datta, Subhan Danish and Shah Fahad for their significant technical writing and improvement of manuscript quality. The authors extend their appreciation to Taif University for funding current work by Taif University Researchers Supporting Project number (TURSP-2020/295), Taif University, Taif, Saudi Arabia.

Conflicts of Interest: The authors declare no conflict of interest. 


\section{References}

1. Pellegrini, P.; Fernández, R.J. Crop intensification, land use, and on-farm energy-use efficiency during the worldwide spread of the green revolution. Proc. Natl. Acad. Sci. USA 2018, 115, 2335-2340. [CrossRef]

2. Zhou, J.B.; Chen, Z.J.; Liu, X.J.; Zhai, B.N.; Powlson, D.S. Nitrate accumulation in soil profiles under seasonally open "sunlight greenhouses" in northwest China and potential for leaching loss during summer fallow. Soil Use Manag. 2010, 26, 332-339. [CrossRef]

3. Hijbeek, R.; Ten Berge, H.F.; Whitmore, A.P.; Barkusky, D.; Schröder, J.J.; Van Ittersum, M.K. Nitrogen fertiliser replacement values for organic amendments appear to increase with N application rates. Nutr. Cycl. Agroecosystems 2018, 110, 105-115. [CrossRef]

4. Rahman, M.H.; Ahmad, I.; Wang, D.; Fahad, S.; Afzal, M.; Ghaffar, A.; Saddique, Q.; Khan, M.A.; Saud, S.; Hassan, S.; et al. Influence of semi-arid environment on radiation use efficiency and other growth attributes of lentil crop. Environ. Sci. Pollut. Res. 2021, 28, 13697-13711. [CrossRef] [PubMed]

5. Lehmann, J.; Joseph, S. (Eds.) Biochar for Environmental Management: Science, Technology, and Implementation; Routledge: London, UK, 2015.

6. Schofield, H.K.; Pettitt, T.R.; Tappin, A.D.; Rollinson, G.K.; Fitzsimons, M.F. Biochar Incorporation Increased Nitrogen and Carbon Retention in a Waste-Derived Soil; Sci. Total. Environ. 2019, 690, 1228-1236. [CrossRef]

7. Kammann, C.; Ratering, S.; Eckhard, C.; Müller, C. Biochar and hydrochar effects on greenhouse gas (carbon dioxide, nitrous oxide, and methane) fluxes from soils. J. Environ. Qual. 2012, 41, 1052-1066. [CrossRef] [PubMed]

8. Haider, G.; Koyro, H.W.; Azam, F.; Steffens, D.; Müller, C.; Kammann, C. Biochar but not humic acid product amendment affected maize yields via improving plant-soil moisture relations. Plant Soil 2015, 395, 141-157. [CrossRef]

9. Haider, G.; Steffens, D.; Müller, C.; Kammann, C.I. Standard extraction methods may underestimate nitrate stocks captured by field-aged biochar. J. Environ. Qual. 2016, 45, 1196-1204. [CrossRef] [PubMed]

10. Haider, G.; Steffens, D.; Moser, G.; Müller, C.; Kammann, C.I. Biochar reduced nitrate leaching and improved soil moisture content without yield improvements in a four-year field study. Agric. Ecosyst. Environ. 2017, 237, 80-94. [CrossRef]

11. Kammann, C.I.; Schmidt, H.P.; Messerschmidt, N.; Linsel, S.; Steffens, D.; Müller, C.; Koyro, H.W.; Conte, P.; Joseph, S. Plant growth improvement mediated by nitrate capture in co-composted biochar. Sci. Rep. 2015, 5, 1-3.

12. Haider, G.; Joseph, S.; Steffens, D.; Müller, C.; Taherymoosavi, S.; Mitchell, D.; Kammann, C.I. Mineral nitrogen captured in field-aged biochar is plant-available. Sci. Rep. 2020, 10, 1-2. [CrossRef] [PubMed]

13. Ummenhofer, C.C.; Meehl, G.A. Extreme weather and climate events with ecological relevance: A review. Philos. Trans. R. Soc. B Biol. Sci. 2017, 372. [CrossRef] [PubMed]

14. GOP. Pakistan Economic Survey 2017-2018; Finance Division, Economic Advisor's Wing: Islamabad, Pakistan, 2018.

15. Wang, X.; Zeng, J.; Li, Y.; Rong, X.; Sun, J.; Sun, T.; Li, M.; Wang, L.; Feng, Y.; Chai, R.; et al. Expression of TaWRKY44, a wheat WRKY gene, in transgenic tobacco confers multiple abiotic stress tolerances. Front. Plant Sci. 2015, 6, 615. [CrossRef] [PubMed]

16. Juknys, R.; Velička, R.; Kanapickas, A.; Kriaučiūnienè, Z.; Masilionytė, L.; Vagusevičienė, I.; Pupalienè, R.; Klepeckas, M.; Sujetovienè, G. Projecting the impact of climate change on phenology of winter wheat in northern Lithuania. Int. J. Biometeorol. 2017, 61, 1765-1775. [CrossRef] [PubMed]

17. Tao, Z.; Shen, L.; Gu, X.; Wang, Y.; Yu, H.; He, Y. Embryonic epigenetic reprogramming by a pioneer transcription factor in plants. Nature 2017, 551, 124-128. [CrossRef] [PubMed]

18. Rahman, M.H.; Ahmad, A.; Wang, X.; Wajid, A.; Nasim, W.; Hussain, M.; Ahmad, B.; Ahmad, I.; Ali, Z.; Ishaque, W.; et al. Multi-model projections of future climate and climate change impacts uncertainty assessment for cotton production in Pakistan. Agric. For. Meteorol. 2018, 253, 94-113. [CrossRef]

19. Glass, A.D. Nitrogen use efficiency of crop plants: Physiological constraints upon nitrogen absorption. Crit. Rev. Plant Sci. 2003, 22, 453-470. [CrossRef]

20. Davis, M.P.; David, M.B.; Mitchell, C.A. Nitrogen mineralization in soils used for biofuel crops. Commun. Soil Sci. Plant Anal. 2013, 44, 987-995. [CrossRef]

21. Robertson, G.P.; Vitousek, P.M. Nitrogen in agriculture: Balancing the cost of an essential resource. Annu. Rev. Environ. Resour. 2009, 34, 97-125. [CrossRef]

22. Roberts, K.G.; Gloy, B.A.; Joseph, S.; Scott, N.R.; Lehmann, J. Life cycle assessment of biochar systems: Estimating the energetic, economic, and climate change potential. Environ. Sci. Technol. 2010, 44, 827-833. [CrossRef] [PubMed]

23. Schimel, J.P.; Bennett, J. Nitrogen mineralization: Challenges of a changing paradigm. Ecology 2004, 85, 591-602. [CrossRef]

24. Wang, S.; Shan, J.; Xia, Y.; Tang, Q.; Xia, L.; Lin, J.; Yan, X. Different effects of biochar and a nitrification inhibitor application on paddy soil denitrification: A field experiment over two consecutive rice-growing seasons. Sci. Total. Environ. 2017, 593, 347-356. [CrossRef] [PubMed]

25. Zhang, Z.; Gao, S.; Chu, C. Improvement of nutrient use efficiency in rice: Current toolbox and future perspectives. Theor. Appl. Genet. 2020, 133, 1365-1384. [CrossRef] [PubMed]

26. Azimi, S.M.; Farnia, A.; Shaban, M.; Lak, M. Effect of different biofertilizers on Seed yield of barley (Hurdeom vulgar L.), Bahman cultivar. Int. J. Adv. Biol. Biomed. Res. 2013, 1, 538-546.

27. Dal Cortivo, C.; Ferrari, M.; Visioli, G.; Lauro, M.; Fornasier, F.; Barion, G.; Panozzo, A.; Vamerali, T. Effects of seed-applied biofertilizers on rhizosphere biodiversity and growth of common wheat (Triticum aestivum L.) in the field. Front. Plant Sci. 2020, 11, 72. [CrossRef] [PubMed] 
28. Gupta, G.; Parihar, S.S.; Ahirwar, N.K.; Snehi, S.K.; Singh, V. Plant growth promoting rhizobacteria (PGPR): Current and future prospects for development of sustainable agriculture. J. Microb. Biochem. Technol. 2015, 7, 96-102.

29. Igiehon, N.O.; Babalola, O.O. Biofertilizers and sustainable agriculture: Exploring arbuscular mycorrhizal fungi. Appl. Microbiol. Biotechnol. 2017, 101, 4871-4881. [CrossRef]

30. Nadeem, S.M.; Naveed, M.; Zahir, Z.A.; Asghar, H.N. Plant-microbe interactions for sustainable agriculture: Fundamentals and recent advances. Plant Microbe Symbiosis Fundam. Adv. 2013, 51-103. [CrossRef]

31. Zeffa, D.M.; Perini, L.J.; Silva, M.B.; de Sousa, N.V.; Scapim, C.A.; Oliveira, A.L.; Amaral Júnior, A.T.; Azeredo Goncalves, L.S. Azospirillum brasilense promotes increases in growth and nitrogen use efficiency of maize genotypes. PLoS ONE 2019, 14, e0215332. [CrossRef]

32. Vejan, P.; Abdullah, R.; Khadiran, T.; Ismail, S.; Nasrulhaq Boyce, A. Role of plant growth promoting rhizobacteria in agricultural sustainability-A review. Molecules 2016, 21, 573. [CrossRef]

33. Sarfraz, R.; Hussain, A.; Sabir, A.; Fekih, I.B.; Ditta, A.; Xing, S. Role of biochar and plant growth promoting rhizobacteria to enhance soil carbon sequestration-A review. Environ. Monit. Assess. 2019, 191, 1-3. [CrossRef] [PubMed]

34. Arabi, Z.; Eghtedaey, H.; Gharehchmaghloo, B.; Faraji, A. Effects of biochar and bio-fertilizer on yield and qualitative properties of soybean and some chemical properties of soil. Arab. J. Geosci. 2018, 11, 1-9. [CrossRef]

35. Cornelissen, G.; Pandit, N.R.; Taylor, P.; Pandit, B.H.; Sparrevik, M.; Schmidt, H.P. Emissions and char quality of flame-curtain" Kon Tiki" Kilns for Farmer-Scale charcoal/biochar production. PLoS ONE 2016, 11, e0154617. [CrossRef] [PubMed]

36. Watson, D.J. The physiological basis of variation in yield. Adv. Agron. 1947, 4, 101-145.

37. Hunt, R. Plant Growth Analysis; Edward Arnold: London, UK, 1978; pp. 26-38.

38. Solarova, J.; Gardner, F.P.; Pearce, R.B.; Mitchell, R.L. Physiology of Crop Plants. Biol. Plant 1987, 29, 21. [CrossRef]

39. Monteith, J.L. Plant growth analysis, radiation use efficiency. Philos. Trans. R. Soc. Ann. Bot. 1977, 14, $21-25$.

40. Monteith, J.L.; Elston, J.F. Performance and productivity of foliage in field. In The Growth and Functioning of Leaves; Dale, J.E., Milthorpe Camb, F.L., Eds.; Cambridge University Press: London, UK, 1983; pp. 499-518.

41. Pradhan, S.; Sehgal, V.K.; Bandyopadhyay, K.K.; Panigrahi, P.; Parihar, C.M.; Jat, S.L. Radiation interception, extinction coefficient and use efficiency of wheat crop at various irrigation and nitrogen levels in a semi-arid location. Indian J. Plant Physiol. 2018, 23, 416-425. [CrossRef]

42. Yunusa, I.A.; Siddique, K.H.; Belford, R.K.; Karimi, M.M. Effect of canopy structure on efficiency of radiation interception and use in spring wheat cultivars during the pre-anthesis period in a Mediterranean-type environment. Field Crop. Res. 1993, 35, 113-122. [CrossRef]

43. Muurinen, S.; Peltonen-Sainio, P. Radiation-use efficiency of modern and old spring cereal cultivars and its response to nitrogen in northern growing conditions. Field Crop. Res. 2006, 96, 363-373. [CrossRef]

44. Angstrom, A. Solar and terrestrial radiation. Report to the international commission for solar research on actinometric investigations of solar and atmospheric radiation. Q. J. R. Meteorol. Soc. 1924, 50, 121-126. [CrossRef]

45. Monteith, J.L.; Unsworth, M.H. Principles of Environmental Physics; Hodder and Stoughton: London, UK, 1990.

46. Monteith, J.L. Solar radiation and productivity in tropical ecosystems. J Appl. Ecol. 1977, 9, 747-766. [CrossRef]

47. FAO Panel of Experts on Pesticide Residues; WHO Expert Group on Pesticide Residues. Pesticides Residues in Food, 1977 Evaluations: The Monographs: Data and Recommendations of the Joint Meeting of the FAO Panel of Experts on Pesticide Residues and the Environment and the WHO Expert Group of Pesticide Residues, Geneva, 6-15 December 1977; Food Agriculture Organization: Rome, Italy, 1978.

48. Cataldo, D.A.; Maroon, M.; Schrader, L.E.; Youngs, V.L. Rapid colorimetric determination of nitrate in plant tissue by nitration of salicylic acid. Commun. Soil Sci. Plant Anal. 1975, 6, 71-80. [CrossRef]

49. Ali, M.A.; Louche, J.; Legname, E.; Duchemin, M.; Plassard, C. Pinus pinaster seedlings and their fungal symbionts show high plasticity in phosphorus acquisition in acidic soils. Tree Physiol. 2009, 29, 1587-1597. [CrossRef] [PubMed]

50. Qayyum, M.F.; Steffens, D.; Reisenauer, H.P.; Schubert, S. Kinetics of carbon mineralization of biochars compared with wheat straw in three soils. J. Environ. Qual. 2012, 41, 1210-1220. [CrossRef] [PubMed]

51. SAS Institute Inc. SAS®9.4 Guide to Software Updates; SAS Institute Inc.: Cary, NC, USA, 2013.

52. Cybulak, M.; Sokołowska, Z.; Boguta, P. Impact of biochar on physicochemical properties of haplic luvisol soil under different land use: A plot experiment. Agronomy 2019, 9, 531. [CrossRef]

53. Thies, J.E.; Rillig, M.C. Characteristics of biochar: Biological properties. Biochar for environmental management: Sci. Technol. 2009, 1, 85-105.

54. Danish, S.; Zafar-ul-Hye, M.; Hussain, M.; Shaaban, M.; Núñez-delgado, A. Rhizobacteria with ACC-Deaminase Activity Improve Nutrient Uptake, Chlorophyll Contents and Early Seedling Growth of Wheat under PEG- Induced Osmotic Stress. Int. J. Agric. Biol. 2019, 21, 1212-1220.

55. Danish, S.; Zafar-ul-Hye, M. Co-application of ACC-deaminase producing PGPR and timber-waste biochar improves pigments formation, growth and yield of wheat under drought stress. Sci. Rep. 2019, 9, 5999. [CrossRef]

56. Zafar-ul-Hye, M.; Zahra, M.B.; Danish, S.; Abbas, M.; Rehim, A.; Akbar, M.N.; Iftikhar, A.; Gul, M.; Nazir, I.; Abid, M.; et al. Multi-strain inoculation with pgpr producing acc deaminase is more effective than single-strain inoculation to improve wheat (Triticum aestivum) growth and yield. Phyton (B. Aires) 2020, 89, 405-413. [CrossRef] 
57. Danish, S.; Zafar-ul-Hye, M. Combined role of ACC deaminase producing bacteria and biochar on cereals productivity under drought. Phyton (B. Aires) 2020, 89, 217-227. [CrossRef]

58. Ahmed, N.; Ahsen, S.; Ali, M.A.; Hussain, M.B.; Hussain, S.B.; Rasheed, M.K.; Butt, B.; Irshad, I.; Danish, S. Rhizobacteria and silicon synergy modulates the growth, nutrition and yield of mungbean under saline soil. Pak. J. Bot. 2020, 52, 9-15. [CrossRef]

59. Danish, S.; Kiran, S.; Fahad, S.; Ahmad, N.; Ali, M.A.; Tahir, F.A.; Rasheed, M.K.; Shahzad, K.; Li, X.; Wang, D.; et al. Alleviation of chromium toxicity in maize by Fe fortification and chromium tolerant ACC deaminase producing plant growth promoting rhizobacteria. Ecotoxicol. Environ. Saf. 2019, 185, 109706. [CrossRef]

60. Danish, S.; Zafar-ul-Hye, M.; Fahad, S.; Saud, S.; Brtnicky, M.; Hammerschmiedt, T.; Datta, R. Drought stress alleviation by ACC deaminase producing Achromobacter xylosoxidans and Enterobacter cloacae, with and without timber waste biochar in maize. Sustainability 2020, 12, 6286. [CrossRef]

61. Woolf, D.; Amonette, J.E.; Street-Perrott, F.A.; Lehmann, J.; Joseph, S. Sustainable biochar to mitigate global climate change. Nat. Commun. 2010, 1, 1-9. [CrossRef]

62. Steinbeiss, S.; Gleixner, G.; Antonietti, M. Effect of biochar amendment on soil carbon balance and soil microbial activity. Soil. Biol. Biochem. 2009, 41, 1301-1310. [CrossRef]

63. Van Zwieten, L.; Kimber, S.; Morris, S.; Chan, K.Y.; Downie, A.; Rust, J.; Joseph, S.; Cowie, A. Effects of biochar from slow pyrolysis of papermill waste on agronomic performance and soil fertility. Plant Soil 2010, 327, 235-246. [CrossRef]

64. Akhtar, S.S.; Li, G.; Andersen, M.N.; Liu, F. Biochar enhances yield and quality of tomato under reduced irrigation. Agric. Water Manag. 2014, 138, 37-44. [CrossRef]

65. Asadi, M.; Kumar, B.; Behranginia, A.; Rosen, B.A.; Baskin, A.; Repnin, N.; Pisasale, D.; Phillips, P.; Zhu, W.; Haasch, R.; et al. Robust carbon dioxide reduction on molybdenum disulphide edges. Nat. Commun. 2014, 5, 1-8. [CrossRef] [PubMed]

66. Schulz, H.; Glaser, B. Effects of biochar compared to organic and inorganic fertilizers on soil quality and plant growth in a greenhouse experiment. J. Plant Nutr. Soil Sci. 2012, 175, 410-422. [CrossRef]

67. Namgay, T.; Singh, B.; Singh, B.P. Influence of biochar application to soil on the availability of As, Cd, Cu, Pb, and Zn to maize (Zea mays L.). Soil Res. 2010, 48, 638-647. [CrossRef]

68. Chan, K.Y.; Van Zwieten, L.; Meszaros, I.; Downie, A.; Joseph, S. Agronomic values of greenwaste biochar as a soil amendment. Soil Res. 2008, 45, 629-634. [CrossRef]

69. Lehmann, J.; da Silva, J.P.; Steiner, C.; Nehls, T.; Zech, W.; Glaser, B. Nutrient availability and leaching in an archaeological Anthrosol and a Ferralsol of the Central Amazon basin: Fertilizer, manure, and charcoal amendments. Plant Soil 2003, 249, 343-357. [CrossRef]

70. Zhang, D.; Yan, M.; Niu, Y.; Liu, X.; van Zwieten, L.; Chen, D.; Bian, R.; Cheng, K.; Li, L.; Joseph, S.; et al. Is current biochar research addressing global soil constraints for sustainable agriculture? Agric. Ecosyst. Environ. 2016, 226, 25-32. [CrossRef]

71. Knowles, O.A.; Robinson, B.H.; Contangelo, A.; Clucas, L. Biochar for the mitigation of nitrate leaching from soil amended with biosolids. Sci. Total Environ. 2011, 409, 3206-3210. [CrossRef] [PubMed]

72. Tariq, M.; Khan, F.; Shah, A.H.; Fahad, S.; Wahid, F.; Ali, J.; Adnan, M.; Ahmad, M.; Irfan, M.; Zafar-ul-Hye, M. Effect of micronutrients foliar supplementation on the production and eminence of plum (Prunus domestica L.). Qual. Assur. Saf. Crop. Foods 2020, 12, 32-40.

73. Izhar Shafi, M.; Adnan, M.; Fahad, S.; Wahid, F.; Khan, A.; Yue, Z.; Danish, S.; Zafar-ul-Hye, M.; Brtnicky, M.; Datta, R. Application of Single Superphosphate with Humic Acid Improves the Growth, Yield and Phosphorus Uptake of Wheat (Triticum aestivum L.) in Calcareous Soil. Agronomy 2020, 10, 1224. [CrossRef]

74. Guo, M.; Uchimiya, S.M.; He, Z. Agricultural and environmental applications of biochar: Advances and barriers. Agricultural and Environ. Appl. Biochar Adv. Barriers 2016, 63, 495-504.

75. Zafar-ul-Hye, M.; Tahzeeb-ul-Hassan, M.; Abid, M.; Fahad, S.; Brtnicky, M.; Dokulilova, T.; Datta, R.; Danish, S. Author Correction: Potential role of compost mixed biochar with rhizobacteria in mitigating lead toxicity in spinach. Sci. Rep. 2020, 10. [CrossRef] [PubMed]

76. Dong, X.; Guan, T.; Li, G.; Lin, Q.; Zhao, X. Long-term effects of biochar amount on the content and composition of organic matter in soil aggregates under field conditions. J. Soils Sediments 2016, 16, 1481-1497. [CrossRef]

77. Shahzad, K.; Abid, M.; Sintim, H.Y. Wheat productivity and economic implications of biochar and inorganic nitrogen application. Agron. J. 2018, 110, 2259-2267. [CrossRef]

78. Ghafoor, I.; Habib-ur-Rahman, M.; Ali, M.; Afzal, M.; Ahmed, W.; Gaiser, T.; Ghaffar, A. Slow-release nitrogen fertilizers enhance growth, yield, NUE in wheat crop and reduce nitrogen losses under an arid environment. Environ. Sci. Pollut. Res. 2021. [CrossRef] [PubMed]

79. Ekielski, A.; Mishra, P.K. Lignin for Bioeconomy: The Present and Future Role of Technical Lignin. Int. J. Mol. Sci. 2021, 22, 63. [CrossRef] [PubMed]

80. Zafar-ul-Hye, M.; Naeem, M.; Danish, S.; Fahad, S.; Datta, R.; Abbas, M.; Rahi, A.A.; Brtnicky, M.; Holátko, J.; Tarar, Z.H.; et al. Alleviation of Cadmium Adverse Effects by Improving Nutrients Uptake in Bitter Gourd through Cadmium Tolerant Rhizobacteria. Environments 2020, 7, 54. [CrossRef]

81. Haider, I.; Raza, M.A.S.; Iqbal, R.; Aslam, M.U.; Habib-ur-Rahman, M.; Raja, S.; Khan, M.T.; Aslam, M.M.; Waqas, M.; Ahmad, S. Potential effects of biochar application on mitigating the drought stress implications on wheat (Triticum aestivum L.) under various growth stages. J. Saudi Chem. Soc. 2020, 24, 974-981. [CrossRef] 
82. Perveen, S.; Ahmad, S.; Skalicky, M.; Hussain, I.; Habibur-Rahman, M.; Ghaffar, A.; Shafqat Bashir, M.; Batool, M.; Hassan, M.M.; Brestic, M.; et al. Assessing the Potential of Polymer Coated Urea and Sulphur Fertilization on Growth, Physiology, Yield, Oil Contents and Nitrogen Use Efficiency of Sunflower Crop under Arid. Environ. Agron. 2021, 11, 269. [CrossRef]

83. Rahman, M.H.U.; Ahmad, A.; Wajid, A.; Hussain, M.; Rasul, F.; Ishaque, W.; Islam, M.A.; Shelia, V.; Awais, M.; Ullah, A.; et al. Application of CSM-CROPGRO-Cotton model for cultivars and optimum planting dates: Evaluation in changing semi-arid climate. Field Crop. Res. 2019, 238. [CrossRef]

84. Ahmad, S.; Ghaffar, A.; Rahman, M.H.U.; Hussain, I.; Iqbal, R.; Haider, G.; Khan, M.A.; Ikram, R.M.; Hussnain, H.; Bashir, M.S. Effect of Application of Biochar, Poultry and Farmyard Manures in Combination with Synthetic Fertilizers on Soil Fertility and Cotton Productivity under Arid Environment. Commun. Soil Sci. Plant Anal. 2021, 1-14. [CrossRef]

85. Khan, A.; Fahad, S.; Khan, A.; Saud, S.; Adnan, M.; Wahid, F.; Noor, M.; Nasim, W.; Hammad, H.M.; Bakhat, H.F.; et al. Managing tillage operation and manure to restore soil carbon stocks in wheat-maize cropping system. Agron. J. 2019, 111, $2600-2609$. [CrossRef] 